\title{
SINFONISMO en el cine
}

\section{Raciel D. Martínez Gómez}

\section{En México destacó la música de Silvestre Re- vueltas en cintas como Vámonos con Pancho Villa (1935) de Fernando de Fuentes y Redes (1936) de Fred Zinnemann; par de películas consideradas como imprescindibles para en- tender el canon mexicano.}

N i duda cabe que la fastuosidad evocada por la música de orquesta permite al cine trascender de la mera eficacia narrativa hacia propósitos artísticos más sofisticados. Acompaña a la definición de personajes, infunde un carácter dramático a la acción con notable aspiración atmosférica y potencia aún más las emociones. Con esta noción en mente, repasemos algunas muestras emblemáticas del uso del sinfonismo en el cine.

De la primera de ellas surgió una polémica de índole ideológica. La música de Richard Wagner le sirvió a David Ward Griffith para pincelar su mural histórico de los Estados Unidos en El nacimiento de una nación (1915); sumado al controvertido halo antisemita que llevaba a cuestas Wagner (Steiner, 2019), la cinta fue acusada de racista al enaltecer la supremacía blanca. Más de medio siglo después, Francis Ford Coppola invierte el sentido, pues la propia épica de la Cabalgata de las valquirias utilizada por Griffith sirve de fondo para uno de los episodios más oscuros de la condición humana: Apocalypse Now (1979), descartando cualquier especulación sobre la superioridad de alguna raza.

Alexander Nevsky (1938) es de los ejemplos más célebres del sinfonismo en el cine. Dirigida por Serguéi Eisenstein, Nevsky es una especie de laboratorio de creación sonora. Para la escena de la batalla -cuenta el mismo Eisenstein (1986) - buscaba una distinción para narrar la gloria del príncipe.
Relata que le costó trabajo explicarle su intención a Serguéi Prokófiev; incluso asegura que mandó elaborar unos instrumentos y entonces fue como le entendió el músico. En el corte final pareciera que Prokófiev hubiera concebido la música de antemano; pero no, la unificación de las secuencias fue una ardua labor para amalgamar las imágenes a través de la música (aunque hubo partes donde sucedió al revés). Finalmente, el resultado de Alexander Nevsky es que apreciamos uno de los filmes más acertados en donde el compositor escribe su equivalente visual.

Lo que el viento se llevó (1939), dirigida por Victor Fleming, también es un caso destacado de sinfonía con miras altas. Más allá del evidente carácter romántico e histórico del filme, el deseo de Max Steiner fue componer una sinfonía con rasgo social que contuviera un paisaje a su vez político. Steiner, en efecto, combina temas patrióticos y populares; sin embargo, lo más trascendente es que dedica su composición a Tara, el extenso plantío de algodón. De acuerdo con Téllez (2013), el score de Steiner fue pensado como una reivindicación de la propiedad tan desigualmente distribuida.

Walt Disney hizo lo propio en Fantasía (1940), película de dibujos animados que utiliza con notable éxito sintáctico la música clásica. Leopold Stokowski, con el propósito de vestir las ocho secuencias del filme, seleccionó piezas de Johann Sebastian Bach, El cascanueces de Piotr Ilich Tchaikovsky, Paul Dukas para el bellísimo El aprendiz de brujo, Ígor Stravinski, Ludwig van Beethoven, Amilcare Ponchielli, Modest Mussorgski y Franz Schubert. Stokowski integra en Fantasía un discurso plástico inédito (la suma dialéctica de dos códigos) y al mismo tiempo otorga carta de mayoría de edad al género infantil. 
Bernard Herrmann es de igual forma uno de los compositores más significativos por su temperamento iconoclasta. Recordemos nada más su innovadora música para El ciudadano Kane (1941), dirigida por Orson Welles; Vértigo (1958), Psicosis (1960) y Los pájaros (1963) de Alfred Hitchcock; o sus últimos trabajos con Martin Scorsese, como Taxi Driver (1976). La obra de Herrmann se distingue por un acento exacerbado, por colocarse de forma descarada en un nivel artificial y todavía así apoderarse del nivel expresivo fílmico. Recordemos que Herrmann había conocido a Welles desde 1938, ya que le había musicalizado la adaptación radiofónica de La guerra de los mundos, la novela de H. G. Wells. La realización tuvo tal impacto entre la opinión pública que revolucionó el concepto de la comunicación de masas.

En México destacó la música de Silvestre Revueltas en cintas como Vámonos con Pancho Villa (1935) de Fernando de Fuentes y Redes (1936) de Fred Zinnemann; par de películas consideradas como imprescindibles para entender el canon mexicano. Revueltas también hizo la música de La noche de los mayas (1939), dirigida por Chano Urueta, con argumento de Salvador Novo y actuación de Mario Moreno, Cantinflas. Silvestre también colaboró con Chano en Los de abajo (1940). Revueltas pronto se convirtió en la referencia más respetada del cine mexicano del siglo pasado; y es que no solamente se erigía como el más digno representante de la música nacionalista, sino que también era reconocido por musicólogos internacionales que lo situaban como un compositor universal.

Otro connotado músico de escuela fue Raúl Lavista, distante de la figura de Silvestre, pero no con menos calidad. Alumno del

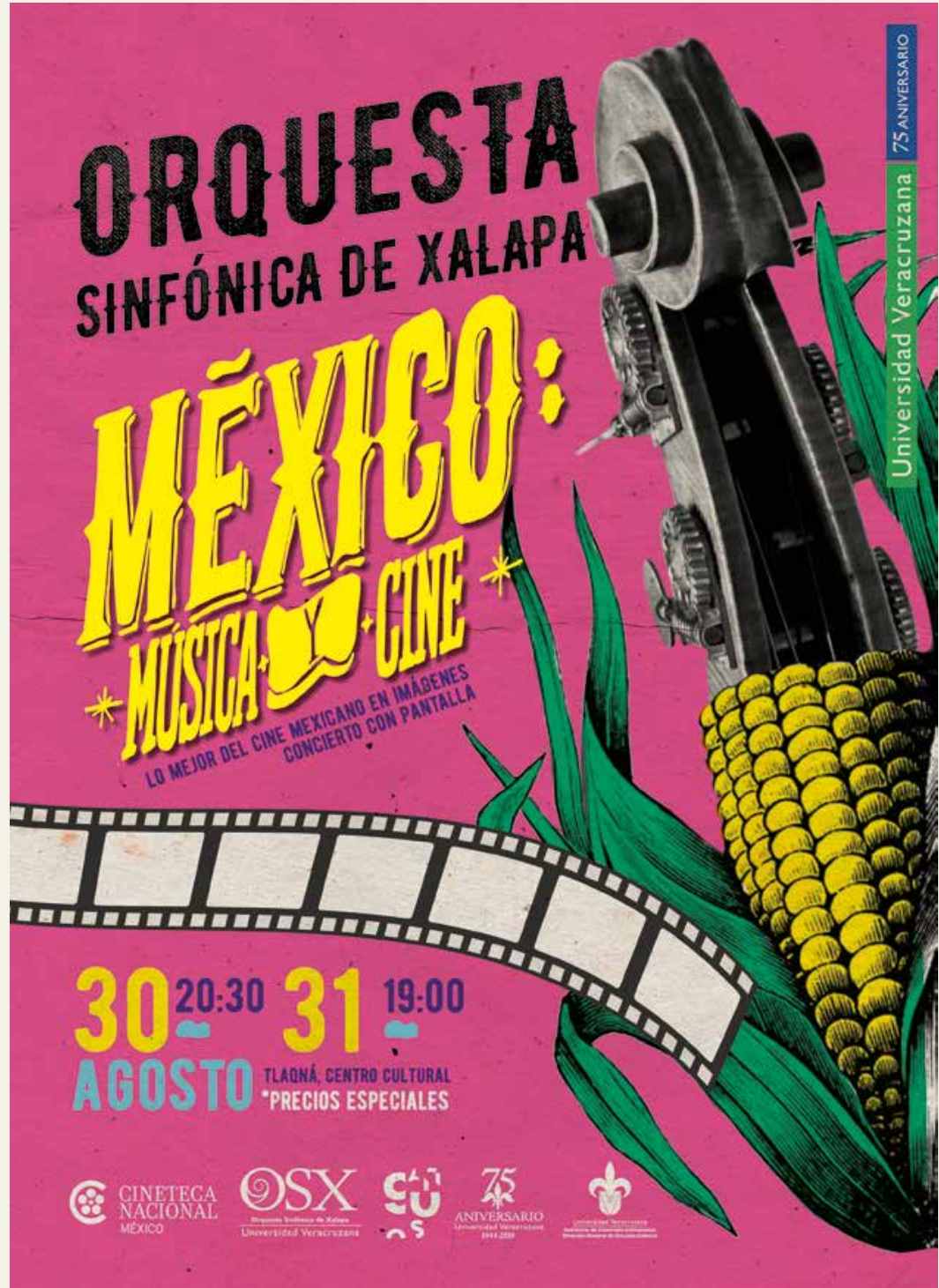

Diseño: Sinsuni E. Velasco Gutiérrez.

mismo Revueltas y de Manuel M. Ponce, Lavista fue un puntal para musicalizar películas en la época de oro del cine mexicano. Realizó el score de joyas del cine popular y de arte como Una familia de tantas (1949) de Alejandro Galindo, El ángel exterminador (1962) de Luis Buñuel y Macario (1959) de Roberto Gavaldón. En medio siglo el maestro Lavista musicalizó más de trescientas películas. Trabajó mucho al lado de Juan Bustillo Oro: Dos monjes (1934) y Ahí está el detalle (1940); y con Ismael Rodríguez en ATM (A toda máquina)
(1951), ¡Mátenme porque me muero! (1951) y ¿Qué te ha dado esa mujer? (1951), entre otros grandes directores de la época de oro.

Ahora bien, el sinfonismo no ha tenido un desarrollo lineal $\mathrm{ni}$ existe, en rigor, una práctica vuelta tradición. No. Fantasía, ya decíamos, fue uno de los ejemplos del novedoso uso del sinfonismo; veamos otros que dieron un giro total ofreciendo matices con la aparición del mainstream.

La era del sinfonismo comercial es iniciada por La guerra de las galaxias (1977), película de 
George Lucas. Fue John Williams quien, con su partitura, planteó un paradigma a seguir en una coyuntura donde Hollywood se apodera del público tras el descenso del cine de autor y el fin de las corrientes cinematográficas. Williams previamente había participado en Tiburón (1975), dirigida por Steven Spielberg, creando con fagotes y cuernos el entorno del mal ubicuamente oculto en el océano. Y, por supuesto, Williams además talló el encanto de $E T, e l$ extraterrestre (1982), del propio Spielberg.

Howard Shore también aportó con su estilo a la historia del cine. Shore compuso la música de la saga de El señor de los anillos (2001, 2002 y 2003), apreciada por varios especialistas como la mejor música escrita para cine, así como la de la trilogía de El hobbit $(2012,2013$ y 2014). La versatilidad de Shore lo lleva a realizar música para películas de tintes no propiamente épicos, como El silencio de los inocentes (1991) y Filadelfia (1993), de Jonathan Demme, hasta musicalizar discursos más crípticos tendientes al cine de arte como el de David Cronenberg en Spider (2002) o en Cosmópolis (2012), entre otras cintas.

Asimismo resaltemos 2001 : Odisea del espacio (1968), película de ciencia ficción dirigida por Stanley Kubrick. Con el rigor que lo caracterizó, Kubrick combinó música de diferentes épocas para alcanzar un estilo vanguardista. Para rodar elipsis memorables, utilizó autores clásicos y románticos como Richard Strauss - Así

\section{Para rodar elipsis} memorables, utilizó autores clásicos y románticos como

Richard Strauss - Así

habló Zaratustra- y Johann Strauss -EI Danubio azul-, lo mismo que música del siglo $\mathrm{xx}$, como la del connotado compositor soviético Aram Jachaturián o la del húngaro György Ligeti quien, a la postre, se convertiría en autor de otras bandas sonoras de Kubrick, como El resplandor (1980) y Ojos bien cerrados
(1999).

habló Zaratustra-y Johann Strauss -El Danubio azul-, lo mismo que música del siglo xx, como la del connotado compositor soviético Aram Jachaturián o la del húngaro György Ligeti quien, a la postre, se convertiría en autor de otras bandas sonoras de Kubrick, como $E l$ resplandor (1980) y Ojos bien cerrados (1999).

Las anteriores películas son apenas una pequeña muestra de la excelente fusión de lenguajes en apariencia con horizontes diferentes. Música y cine cohabitan sin dificultad. Podríamos asimismo hablar de contribuciones como las de Ennio Morricone con Sergio Leone (El bueno, el malo y el feo, 1966), Hans Zimmer con Rob Minkoff y Roger Allers (El rey león, 1994), Danny Elfman con Tim Burton (Batman, 1989) o de experimentos tipo Birdman (2014), de Antonio Sánchez con Alejandro González Iñárritu. El asunto es que el sinfonismo en el cine carece de límites. Entre más concursa en historias, más posibilidades se desprenden para hacernos reflexionar desde lo más hondo del ser humano. Solo evoquemos al Nino Rota interpretado por la Orquesta Sinfónica Nacional de Dinamarca para tener certeza de que no todo está podrido. ¡Larga vida al sinfonismo en el cine! LPyH

\section{REFERENCIAS}

Eisenstein, Sergei M. 1986. El sentido del cine. México: Siglo XXI.

Steiner, George. 2019. Necesidad de música. Artículos, reseñas y conferencias. Ciudad de México: Grano de sal.

Téllez, José Luis. 2013. Paisajes imaginarios. Escritos sobre música y cine. Madrid: Cátedra.

Raciel D. Martínez Gómez es comunicólogo, doctor en Sociedades Multiculturales y Estudios Interculturales por la Universidad de Granada. Actualmente es director general de Comunicación Universitaria de la UV. 